\title{
Land Governance and Conflict Management in Tanzania: Institutional Capacity and Policy-Legal Framework Challenges
}

\author{
Pius John", Samwel J. Kabote \\ Department of Development Studies, Sokoine University of Agriculture, Morogoro, Tanzania \\ *Corresponding author: piusjn@suanet.ac.tz
}

\begin{abstract}
This paper examines land governance in the Southern Agricultural Growth Corridor in Rukwa and Katavi regions in Tanzania. The four districts involved include Sumbawanga, Kalambo, Nkasi and Mpanda. Land governance and the management of related conflicts were assessed in views of the roles of local government and the challenges posed by policy and legal frameworks. Using a sample size of 270 smallholder farmers, a household survey was used to collect quantitative data, while qualitative data were collected from 74 Focus Group Discussions' participants. The results confirmed the 'legal dualism' that embraces colonial policy and laws on land issues at local level despite the land reforms that have had taken place in Tanzania. In addition, land conflict was a common phenomenon. The results also show that the efforts of local governments, and other stakeholders, to manage land conflicts were hampered by serious challenges. The challenges include incapacitation of the local government with regard to legal issues, lack of education and unawareness of the policies and legal framework on the part of the citizenry. These resulted into ineffective implementation of informal and formal arrangements governing land issues. Ineffective land governance, in turn, stem from inadequate capacity to resolve land conflicts. This justifies poor land governance. To that effect, concerted efforts are needed to correct the situation.
\end{abstract}

Keywords: land, conflict, management, policies, laws, Tanzania

Cite This Article: Pius John, and Samwel J. Kabote, "Land Governance and Conflict Management in Tanzania: Institutional Capacity and Policy-Legal Framework Challenges." American Journal of Rural Development, vol. 5, no. 2 (2017): 46-54. doi: 10.12691/ajrd-5-2-3.

\section{Introduction}

Management of land conflicts forms an essential part of sustaining livelihoods in Tanzania and elsewhere in the world. While this is the case, land governance from the local government grassroots cannot be overemphasized in Africa where the capacity to manage land is low but poverty is rampant. While legal and policy reforms have been carried out from time to time in order to manage conflicts arising from both poor natural resources and land management, challenges at local government level remain unattended. This, in turn, amounts to conflict and inability to achieve Sustainable Development Goals hence jeopardizing the future of the next generation.

Before colonialism, communal land ownership was widespread in Africa. As such, every community member had a right to access and own the land. Land management at that period followed customary land rights, and customary arrangement to resolving land conflict was effective through clan and tribe elders in countries like Tanzania. Colonialism marked the first land tenure reform that introduced the concept of privatization of land mainly to the colonial settlers and a few African landlords. The Land and Natural Resource Tenure in Africa Program (2010) reports that while promoting privatization of land, the Germans in Tanzania for example, converted all territorial lands into 'Crown Lands'. Through this system, whether the land was occupied or not, it was considered as not owned 'Crown Land'. In addition, the coming of the British promoted the basic principles established by the Germans, but also passed the Land Ordinance in 1923 that declared land as a public property under control of the colonial governor. The Land Ordinance formally recognized customary land rights in 1928. As such, African societies including Tanzania saw two land management laws: first, statutory laws governing the privatized land, and second, customary law governing the land under communal ownership. Literature takes this as a 'legal dualism' system and account largely for legalpolicy problems related to land governance.

Basically, majority of the post-independence governments in Africa inherited colonial land laws without considerable changes that could benefit the rural poor. For instance, the 'legal dualism' persisted through post independence period posing challenges to land management, control and ownership, more so among women who are marginalized by the patriarchal system [16]. The promulgation of the land related colonial policies is evident when considering the Village Land Act and Land Act of 1999 that declare land as a public property vested in the president authorities in Tanzania. The laws portray three categories of land including village land that constitutes almost $70 \%$, 
reserved land that constitutes about $28 \%$ and the general land occupying nearly $2 \%$ [12].

Notably, Land alienation from smallholder farmers has increased with liberalization and therefore exacerbating poor customary land tenure security [12]. This phenomenon culminates to land and other natural resource conflicts in African countries [15]. Tanzania is a case in point whereby natural resource conflicts are on the increase because of many factors particularly poor resource governance despite the efforts to improve the situation. The common categories of natural resource conflicts in Tanzania include: conflict between pastoralists and farmers, indigenous and investors, the central government and citizens and conflict between reserved areas authorities and citizens. Such kinds of conflicts affect people's livelihoods by leaving them homeless. Some have lost their lives [2].

Following changes due to liberalization and the land reforms, it is pertinent to argue that changes in land use patterns that have contributed to an increasing trend in land conflicts in African countries like Tanzania [1,8] have already happened. According to Kabote et al. [10] land leasing to private companies, individuals and foreign governments for large scale investment is increasing causing tensions between local communities and foreign investors. This poses worry to the well-being in the villages especially when it is accompanied by farmers' displacements that disturb the rural livelihoods base. Therefore, effective land governance is essential to accommodate the management of land conflict in African countries like Tanzania.

Knowing that land is critical for communities' livelihoods in Tanzania, the country is committed to addressing land issues including conflicts and marginalization of some social groups. For example, in 1991, the government appointed a commission to inquire into land matters. Some of the terms of reference included the following: first, review of laws and policies concerning land allocation, tenure, use and development and to propose reforms on the same; second, to examine the nature of land disputes and conflicts in place and to propose measures for their resolution [3]. Noting a number of policy and legal framework challenges such as allocation of land to foreigners, government encroachment over village land, actions brought forward by former rights-holders and the place of women regarding land ownership in relation to customary law, different measures were suggested by the commission. Yet, since the submission of the report in 1992, some of the contentious issues on land governance and development have been resolved while others remain unresolved. The resolved issues include recognition of the so called village land, the place of a woman in relation to land ownership versus customary law and the distinctions between general land and reserved land [19]. Needless to repeat narrations of these aspects, some challenges on both policy and legal issues are persisting. The next sections of this paper elaborate the methodology used, present and discuss the results and finally chart out conclusions and policy recommendations.

\section{Study Area}

The study was conducted within the Southern Agricultural Growth Corridor in Tanzania (SAGCOT) in Sumbawanga cluster, in Rukwa and Katavi regions, and covered Sumbawanga, Kalambo and Nkasi districts in Rukwa and Mpanda Districts in Katavi Regions. The districts were selected because human population is increasing rapidly in those areas due to a good climatic condition for crop production and livestock keeping relative to other parts in the country. Animal population is also increasing rapidly because of immigration of pastoralists. This is likely to exacerbate land degradation and conflict between farmers and pastoralists or between farmer and a farmer. Four landscapes were involved in the survey including Sumbawanga-Mtowisa, Kasanga-Matai, Kate-Chala and Mwese-Mwamankulu-Sitalike. A landscape is defined, in this paper, as an area of a countryside or land of a particular type, used especially when talking about its appearance. The targeted population were households because land is controlled at a household level. Figure 1 shows the sites involved in the study.

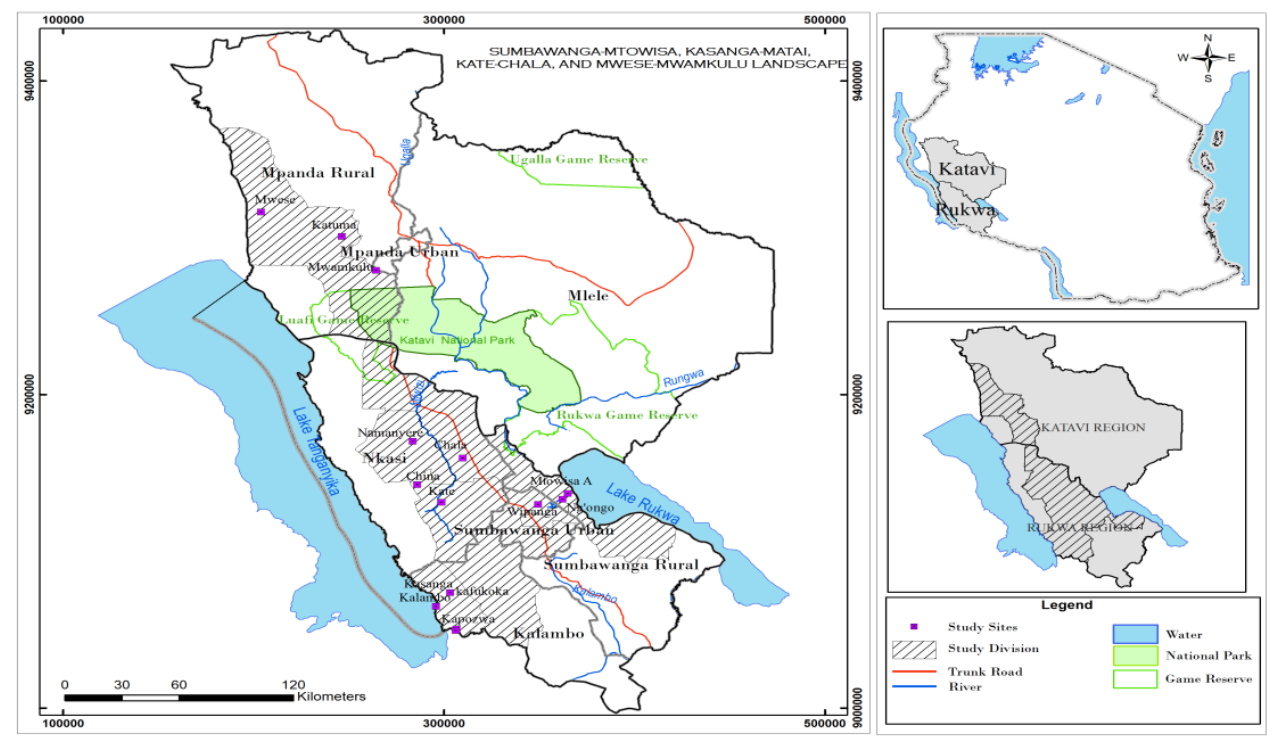

Figure 1. Map showing study sites 


\section{Approaches and Methods}

This study used consultative and participatory approach that involved different land stakeholders. Consequently, the study was open, transparent and it was characterised by a learning process between the research team and the participants. The study employed mixed methods to collect quantitative and qualitative data at a landscape level. The study employed methodological triangulation of quantitative and qualitative techniques. It also adopted a descriptive cross-sectional research design to collect quantitative and qualitative data on key variables one time only from different participants. The study population included smallholder farmers. Local Government Authorities (LGAs) were involved whereby Local Governance Officers were taken as key informants. An existing situation about land conflict was assessed simultaneously among individuals in a well-defined representative sample of the population at one point in time. A combination of simple random sampling and systematic sampling technique was used to select representative households for the survey. The sampling frame was prepared, in each village; with support from village leaders by listing all households in each village selected for the study. The survey involved 9 villages as presented in Table 1 .

\subsection{Data Collection Methods}

Qualitative data were collected through Focus Groups Discussions (FGDs) and key informant interviews by involving Local Government Officers. This covered situational analysis of land resources management, mechanisms, procedures and capacity to resolve land resource conflicts. A checklist of items was used to guide qualitative data collection process. Gender dimension consideration was substantial during selection of FGDs participants because different gender groups tend to exhibit different land interests. To that effect, it was possible to capture information from men and women. One FGD was conducted in each village with participants ranging from 6-10 as shown in Table 2.

On the other hand, collection of quantitative data involved household survey using a questionnaire which was administered to the smallholder farmers at a household level. A sample size of 270 households was involved in the survey, 30 from each village. The respondents were heads of households or their spouses or both, or any other adult person. The questionnaire was the main data collection tool and it was used to collect type of data focusing on relationship between variables. Both closed-ended and open-ended questions were used. The study also used key informant interviews. In addition, one FGD was conducted in each village to collect information on land conflicts and land use management. Participants for FGDs were selected carefully among smallholder farmers by ensuring men and women representation and also representation from resource management committees especially land, forest and the environment in general. The analysis is based on descriptive statistics for quantitative data and content analysis for qualitative data.

Table 1. Villages surveyed for the study

\begin{tabular}{|c|c|c|c|c|c|}
\hline Village name & Landscape & Men population & Women Population & Total Number of Households & Sample Selected \\
\hline Mtowisa A & Sumbawanga - Mtiwisa & 2,010 & 3,030 & 1,006 & 30 \\
\hline Ng'ongo & Sumbawanga - Mtiwisa & 1381 & 1446 & 626 & 30 \\
\hline Wipanga & Sumbawanga - Mtiwisa & 1264 & 1219 & 420 & 30 \\
\hline Kafukoka & Kassanga-Matai & 708 & 915 & 393 & 30 \\
\hline Kassanga & Kassanga-Matai & 1327 & 1953 & 1300 & 30 \\
\hline China & Kate-Chala & 1037 & 1095 & 442 & 30 \\
\hline Chala C & Kate-Chala & 1031 & 1004 & 224 & 30 \\
\hline Katuma & Mwese - Mwamankulu - Sitalike & 3484 & 3540 & 1258 & 30 \\
\hline Mwamkulu & Mwese - Mwamankulu - Sitalike & 1327 & 1953 & 980 & 30 \\
\hline Total sample & \multicolumn{5}{|c|}{270} \\
\hline
\end{tabular}

Table 2. Characteristics of focus group discussions' participants

\begin{tabular}{|l|c|c|c|c|c|c|}
\hline Village name & Men & Women & FGD size & Mean age (years) & Minimum age (years) & Maximum age (years) \\
\hline Mtowisa A & 8 & 2 & 10 & 40 & 30 & 51 \\
\hline Ng'ongo & 5 & 2 & 7 & 36 & 24 & 48 \\
\hline Wipanga & 3 & 3 & 6 & 44 & 24 & 46 \\
\hline Kafukoka & 6 & 3 & 9 & 40 & 32 & 56 \\
\hline Kassanga & 4 & 6 & 10 & 48 & 39 & 64 \\
\hline China & 4 & 2 & 6 & 62 & 28 & 86 \\
\hline Chala C & 6 & 3 & 9 & 37 & 35 & 46 \\
\hline Katuma & 5 & 5 & 10 & 48 & 42 & 62 \\
\hline Mwamankulu & 6 & 1 & 7 & 61 & & 80 \\
\hline
\end{tabular}




\section{Respondents' Characteristics}

Table 3 presents respondents' characteristics. The results show that $78.1 \%$ of the respondents were heads of households. Others were spouses, daughters, sons and other relatives. This implies that the study involved the targeted people who were the household heads.

The high percentage of the household heads is attributed to timing of the survey that was conducted in May 2016. This period, in the study area, is the time when households have finished farming activities awaiting for harvesting. Therefore, most of the heads of household were available at home. The results also showed that $83.7 \%$ of the heads of household were males. This is true for African and in particular for a Tanzanian situation in which the household head is normally a man. In addition, $78.5 \%$ of the respondents were married. This is because the nature of socio-economic activities in rural areas, which is mainly agriculture, requires intensive labour force. Spouses normally perform most of the farming activities in rural Tanzania and are treated as labour producers [9].

Table 3 also shows that $80.4 \%$ of the respondents had primary education level, followed by ordinary secondary education. Education is a key variable for social development. Having respondents with primary education level implies that they were able to count and write and possibly to do simple numeric calculations in addition to simple reasoning related to land conflict and management. It is clear from Table 3 that livelihoods of $91 \%$ of the respondents depended on agriculture, and this was their major occupation, followed by fishing, and Small and Medium Enterprises. Land is critical for farming activities and for supporting livelihoods in Tanzania. Civil servants in the sample were mainly teachers, nurses and agricultural extension officers, possibly because the study was conducted in rural areas. Among the surveyed areas, Sumbawanga-Mtowisa had the highest number of farmers followed by Kate-Chala. The dependence on agriculture reported, in this study, is higher than $66.9 \%$ of employment that agriculture provides at a national level [18]. Other socio-economic activities include livestock keeping, fishing, and small-scale business. Agriculture is mainly rain-fed in the study area. Irrigated agriculture, though is critical for agricultural productivity, is limited and it is taking place in a few isolated traditional irrigation schemes observed at Ng'ongo and Mwamankulu villages.

Table 3. Respondents' characteristics

\begin{tabular}{|c|c|c|c|c|c|}
\hline Variable & $\begin{array}{c}\text { Sumbawanga-Mtowisa } \\
(\mathrm{n}=90)\end{array}$ & $\begin{array}{c}\text { Kasanga- } \\
\text { Matai(n=60) }\end{array}$ & $\begin{array}{l}\text { Mwese-Mwamankulu- } \\
\text { Sitalike(n=60) }\end{array}$ & $\begin{array}{c}\text { Kate-Chala } \\
(\mathbf{n}=60)\end{array}$ & Total $(\mathbf{N}=\mathbf{2 7 0})$ \\
\hline \multicolumn{6}{|c|}{ Relationship with household head } \\
\hline Head of the household & 26.3 & 16.7 & 19.3 & 15.9 & 78.1 \\
\hline Spouse & 5.9 & 4.8 & 2.2 & 5.9 & 18.9 \\
\hline Daughter/Son & 0.7 & 0.4 & 0.7 & 0.7 & 2.6 \\
\hline Other relatives & 0.4 & 0.0 & 0.0 & 0.0 & 0.4 \\
\hline Total & & & & & 100 \\
\hline \multicolumn{6}{|l|}{ Respondents' sex } \\
\hline Male & 26.3 & 19.6 & 18.1 & 19.6 & 83.7 \\
\hline Female & 7.0 & 2.2 & 4.1 & 3.0 & 16.3 \\
\hline Total & & & & & 100 \\
\hline \multicolumn{6}{|l|}{ Respondents' marital status } \\
\hline Married & 25.2 & 18.9 & 15.9 & 18.5 & 78.5 \\
\hline Never Married & 2.6 & 1.1 & 2.2 & 1.1 & 7.0 \\
\hline Divorced/Separated & 2.6 & 0.7 & 2.6 & 1.1 & 7.0 \\
\hline Widower & 0.4 & 0.4 & 0.4 & 0.4 & 1.5 \\
\hline Widow & 2.6 & 0.7 & 1.1 & 1.5 & 5.9 \\
\hline Total & & & & & 100 \\
\hline \multicolumn{6}{|c|}{ Education Level of the respondents } \\
\hline No formal education & 3.7 & 0.4 & 1.1 & 1.5 & 6.7 \\
\hline Primary & 25.2 & 19.3 & 19.3 & 16.7 & 80.4 \\
\hline Ordinary Secondary & 4.1 & 2.2 & 1.5 & 3.7 & 11.5 \\
\hline Advanced secondary & 0.0 & 0.0 & 0.4 & 0.0 & 0.4 \\
\hline Vocational training & 0.0 & 0.0 & 0.0 & 0.4 & 0.4 \\
\hline College & 0.4 & 0.0 & 0.0 & 0.4 & 0.7 \\
\hline Total & & & & & 100 \\
\hline \multicolumn{6}{|c|}{ Respondents' major occupation } \\
\hline Agriculture & 32.6 & 16.7 & 19.6 & 21.9 & 90.7 \\
\hline SME Entrepreneur & 0.0 & 0.7 & 1.5 & 0.4 & 2.6 \\
\hline Natural resources extraction & 0.0 & 0.4 & 0.0 & 0.0 & 0.4 \\
\hline Civil servant & 0.4 & 0.0 & 1.1 & 0.4 & 1.9 \\
\hline Charcoal burning & 0.4 & 0.0 & 0.0 & 0.0 & 0.4 \\
\hline Fishing & 0.0 & 4.1 & 0.0 & 0.0 & 4.1 \\
\hline Total & & & & & 100 \\
\hline
\end{tabular}


Table 4. Methods of land acquisition

\begin{tabular}{|c|c|c|c|c|c|}
\hline Land acquisition & $\begin{array}{c}\text { Sumbawanga-Mtowisa } \\
(\mathrm{n}=90)\end{array}$ & $\begin{array}{c}\text { Kasanga-Matai } \\
(n=60)\end{array}$ & $\begin{array}{c}\text { Mwese-Mwamankulu- } \\
\text { Sitalike }(n=60)\end{array}$ & $\begin{array}{l}\text { Kate-Chala } \\
\qquad(n=60)\end{array}$ & $\begin{array}{c}\text { Total } \\
(n=270)\end{array}$ \\
\hline Purchased & 8.5 & 3.0 & 8.1 & 7.8 & 27.4 \\
\hline Inherited & 16.7 & 12.6 & 7.4 & 10.0 & 46.7 \\
\hline Allocated by the Village Land Committee & 0.4 & 3.0 & 0.4 & 0.0 & 3.7 \\
\hline Rented-In & 6.3 & 0.7 & 5.9 & 1.5 & 14.4 \\
\hline Acquired (Cleared the bush/forest) & 0.7 & 0.7 & 0.0 & 0.7 & 2.2 \\
\hline \multicolumn{5}{|l|}{ Total } & 100.0 \\
\hline
\end{tabular}

\section{Results and Discussion}

\subsection{Institutional Arrangements for Land Acquisition and Land Use Planning}

Table 4 presents land acquisition methods in the landscapes. The results show that $46.7 \%$ of the respondents acquired land through inheritance. A considerable number also acquired land through purchase. Other methods of acquiring land were allocation by the village land committee, renting and borrowing. A few acquired through clearing a bush. The results therefore portray existence of informal and formal institutional arrangements that regulated land acquisition at a village level.

This is consistent with the Tanzania land tenure system and Land Policy and Acts in particular, which give mandate to the Village Councils with the task of land administration in relation to the village land. The legal framework also provides room for customary arrangements with regard to land management $[17,19]$. In Tanzania, land is a public property vested under the President as a trustee on behalf of all citizens [7,17]. Statutory laws in Tanzania provide mandate to the village governments to manage and allocate the village land to community members. In addition, the existence of formal arrangements for land governance was also reported during the interview with the key informants and during FGDs in the landscapes. In Sumbawanga-Mtowisa landscape, for example, it was reported, during FGDs, that land use and planning were categorized into the following aspects: land for grazing, forest reserves and agriculture. It was also reported that breach of these formal arrangements would amount to Tsh. 50,000 in fine (an equivalent of US\$25) or more. These penalties were administered by the village and or ward councils and point out to an indispensable role of local governments in governance of land related resources.

Customary land acquisition arrangements that make use of village elders were also reported during FGDs throughout the landscapes. However, with such arrangements, recognized also by the village land act of 1999, women were victims of land acquisition processes. Consequently, this phenomenon has resulted into few women controlling household land relative to men (Table 4). This is in line with Daley et al. [4] on the argument that there is legal discrimination of women on land issues and, above all, poor enforcement and definitely implementation statutory laws, especially in rural and remote areas, or among minority and indigenous groups. Thus, although the 1999 Land Acts give an opportunity for women to own land, the land allotted through statutory and customary arrangements is owned by the heads of households who happen to be men in most patriarchy societies in Tanzania. Similarly, the Land Policy of Tanzania recognizes that under customary land law, women generally have inferior land rights relative to men and their access to land is indirect and insecure. Thus, with this pre-acknowledgment, the policy still asserts that:

In order to enhance and guarantee women's access to land and security of tenure, women will be entitled to acquire land in their own right not only through purchase but also through allocation. However, inheritance of clan land will continue to be governed by custom and tradition provided such custom and tradition are not contrary to the constitution and not repugnant to the principles of natural justice [17].

Given the context under which customs and traditions operate, coupled with an inadequate knowledge of the citizens and local leaders on land issues, it suffice to argue that customary land law is likely to contradict with statutory land laws. For instance, Wanitzek and Sippel [20] reported that customary and statutory laws are divergent because they pursue different goals in Tanzania. Thus, out of the goals they pursue the laws yield different results in relation to land conflict management. A study by Fauz [6] also observes that while the two categories of land laws (statutory and customary laws) exist in Tanzania, in practice, statutory land laws tend to override customary laws. On one hand, this is true especially when it comes to resolving land conflicts whereby those possessing land through customary laws are subject to losing land either to the state itself as the central authority or to potential buyers for development purposes [13]. On the other hand, Fairley [5] notes that the interpretation of customary right is by itself obscure and a course for land conflicts. At practical level, in developing countries like Tanzania, customary tenure has come to mean current land usage pattern whereby the force of law is given to users of land in their rights to access the land they are currently using. This in turn, creates conflict between land users and those with traditional rights who at times are alienated from their land. During this study, it was also found out that land access by means of statutory arrangements against customary ownership were among the factors causing conflict. An example is drawn from the focus group discussions at China Village:

We have been working on our farmlands from time immemorial through customary arrangements, but this investor has grabbed our land. He is still encroaching on the remaining land. We fear for complete loss of our land in the next few years (China male focus group discussions). 
To address these challenges requires deliberate efforts by the state. First, the state should take action by amending contradictory Acts. Second, the state should not only limit itself to amending legislative frameworks, but should as well proactively engage the community. This should include promoting social change that should also focus on resources and developing specific policies that promote and protect women's land rights and community involvement at large in land governance. With regard to land control presented in Table 5, the results of this paper show that $82.2 \%$ of the respondents reported male domination in land control. This is contrary to the Land Acts of 1999, and National Land Policy of 1995 that give room for women to control and own the land.

It is therefore apparent that the results in Table 5 lead to questioning effectiveness of implementation of the Acts and the policy as well after a period of more than 15 years since their inception. This can be explained largely by poor enforcement of the policy and the laws. These results suggest further the need to promote gender equity interventions to the communities in the landscapes in order to strike the balance between the informal and formal institutional arrangements and the needs of the disadvantaged groups particularly women.

\subsection{Mismanaged Land Allocation as the Cause of Conflicts}

Table 6 presents respondents' responses on issues related to causes of land conflicts.

The results show that $50 \%$ of the respondents reported land allocation through either formal or informal arrangements. Formally, the village council and or village government is responsible for land allocation. About customary arrangements, the clan or elders are responsible to allocate land to the community members. The results however differed by landscapes with Kate-Chala showing highest response on this variable. Table 7 informs unclear land boundary as a major cause of conflict. Basically, land allocation presented in section 5.1 of this paper was not clearly informed about land boundaries. This, according to FGDs participants, resulted into double land allocation and ultimately land conflicts.

Table 5. Control of the household land by gender

\begin{tabular}{|l|c|c|c|c|c|}
\hline $\begin{array}{l}\text { Sex of respondent controlling } \\
\text { household land }\end{array}$ & $\begin{array}{c}\text { Sumbawanga-Mtowisa } \\
(\mathbf{n}=\mathbf{9 0})\end{array}$ & $\begin{array}{c}\text { Kasanga-Matai } \\
(\mathbf{n}=\mathbf{6 0})\end{array}$ & $\begin{array}{c}\text { Mwese-Mwamankulu- } \\
\text { Sitalike }(\mathbf{n}=\mathbf{6 0})\end{array}$ & $\begin{array}{c}\text { Kate-Chala } \\
(\mathbf{n}=\mathbf{6 0})\end{array}$ & $\begin{array}{c}\text { Total } \\
(\mathbf{n}=\mathbf{2 7 0})\end{array}$ \\
\hline Male Head of Household & 27.4 & 18.5 & 16.7 & 19.6 & 82.2 \\
\hline Female Spouse/ Head of Household & 2.2 & 3.0 & 2.2 & 2.6 & 10.0 \\
\hline Both male and female spouses & 3.7 & 0.4 & 3.3 & 0.4 & 7.8 \\
\hline Total & \multicolumn{3}{|l}{} & $\mathbf{1 0 0 . 0}$ \\
\hline
\end{tabular}

Table 6. Major cause of land conflicts in percentages

\begin{tabular}{|c|c|c|c|c|c|}
\hline Causes of land conflicts & $\begin{array}{c}\text { Sumbawanga-Mtowisa } \\
(\mathrm{n}=46)\end{array}$ & $\begin{array}{c}\text { Kasanga-Matai } \\
(\mathrm{n}=41)\end{array}$ & $\begin{array}{l}\text { Mwese-Mwamankulu- } \\
\text { Sitalike }(\mathrm{n}=18)\end{array}$ & $\begin{array}{c}\text { Kate-Chala } \\
(n=41)\end{array}$ & $\begin{array}{c}\text { Total } \\
(n=146)\end{array}$ \\
\hline Land allocation & 15.1 & 9.6 & 9.6 & 15.8 & 50.0 \\
\hline Land scarcity & 4.8 & 7.5 & 0.0 & 2.7 & 15.1 \\
\hline Large scale investment & 0.0 & 0.0 & 0.0 & 6.2 & 6.2 \\
\hline Degradation of land resources & 0.7 & 0.0 & 0.0 & 0.0 & 0.7 \\
\hline Immigrants & 4.8 & 3.4 & 0.7 & 0.7 & 9.6 \\
\hline Poor land use planning & 2.7 & 0.0 & 1.4 & 1.4 & 5.5 \\
\hline Boundaries & 3.4 & 7.5 & 0.7 & 0.7 & 12.3 \\
\hline 11.00 & 0.0 & 0.0 & 0.0 & 0.7 & 0.7 \\
\hline \multicolumn{5}{|l|}{ Total } & 100.0 \\
\hline
\end{tabular}

Table 7. Percentage of households experiencing different types of land-related conflict

\begin{tabular}{|l|c|c|c|c|c|}
\hline Typology of conflicts & $\begin{array}{c}\text { Sumbawanga- } \\
\text { Mtowisa (n=60) }\end{array}$ & $\begin{array}{c}\text { Kasanga- } \\
\text { Matai (n=60) }\end{array}$ & $\begin{array}{c}\text { Mwese-Mwamankulu- } \\
\text { Sitalike (n=63) }\end{array}$ & $\begin{array}{c}\text { Kate-Chala } \\
(\mathbf{n}=\mathbf{6 0})\end{array}$ & $\begin{array}{c}\text { Total } \\
(\mathbf{n}=\mathbf{2 4 3})\end{array}$ \\
\hline Boundary conflicts & 45.0 & 20.0 & 14.3 & 35.0 & 28.4 \\
\hline Inheritance conflicts & 15.0 & 6.7 & 0.0 & 6.7 & 7.0 \\
\hline Ownership conflicts due to legal pluralism & 3.3 & 3.3 & 4.8 & 0.0 & 2.9 \\
\hline Ownership conflicts due to lack of land registration & 11.7 & 0.0 & 0.0 & 3.3 & 3.7 \\
\hline $\begin{array}{l}\text { Ownership conflicts between state and } \\
\text { private/common/collective owners }\end{array}$ & 5.0 & 1.7 & 4.8 & 3.3 & 3.7 \\
\hline Multiple sales/allocations of land & 3.3 & 0.0 & 3.2 & 0.0 & 1.6 \\
\hline $\begin{array}{l}\text { Limited access to land due to discrimination by law, } \\
\text { custom or practise }\end{array}$ & 1.7 & 1.7 & 4.8 & 0.0 & 2.1 \\
\hline $\begin{array}{l}\text { Violent land acquisitions, incl. clashes and wars over } \\
\text { land }\end{array}$ & 0.0 & 0.0 & 0.0 & 0.0 & 0.0 \\
\hline Evictions by land owners & 5.0 & 1.7 & 4.8 & 3.3 & 3.7 \\
\hline $\begin{array}{l}\text { Illegal evictions by state officials acting without } \\
\text { mandate }\end{array}$ & 3.3 & 0.0 & 0.0 & 0.0 & 0.0 \\
\hline Disputes over the payment for using/buying land & 0.0 & 0.0 & 1.6 & 0.0 \\
\hline Disputes over the value of land & 0.0 & 0.0 & 0.0 & 0.0 & 0.4 \\
\hline
\end{tabular}


In addition, it is important to note that lack of awareness of existence of land by-laws caused poor coordination and duplication of activities between formal and informal arrangements and finally resulted into double land allocation. According to the FGDs, land conflicts normally occurred between farmer and farmer, and village and village as reported at Kafukoka village. Some land conflicts were related to land inheritance especially when some of those who inherited the family land wanted to sell it without consent of other family members. A synthesis from FGDs gives the following conflicts typologies:

- Farmer - Pastoralist: these occur frequently and tend to increase in number during agricultural seasons. Last season (2015) the village encountered about 7 , but in 2016 a total of 12 land conflicts occurred and were resolved.

- Village boundaries conflicts: currently, these conflicts exist between Katuma and Kamilale and Katuma and Mnyagala villages. These conflicts have been in existence for more than two years and are yet to be resolved.

- Pastoralists - village governments: these occur when pastoralist graze their livestock around water sources including river Katuma. This conflict in Katuma ward is currently at court level, and resolving this one is very challenging because of poor governance among some local government officers who normally receive bribes from the pastoralists.

It is clear that the efforts of formal and informal arrangements were not coordinated causing overlapping and duplication of the interventions. This paper argues that the results on causes of land conflict imply poor land governance in the landscapes. The results also question coordination and capacity of formal and informal arrangements to govern the village lands. Table 8 shows respondents' responses on awareness of land allocation and land by-laws. Exactly $71.5 \%$ were aware of the existence of by-laws that apply in village land use planning. However, $8.5 \%$ were not aware of land by-laws. Unawareness implies that the by-laws did not influence behaviour of the land users mainly farmers and pastoralists.

A study conducted by Kelsey et al. [11] in Mali points out that to properly govern land it requires awareness of formal institutions and holistic approach that focuses on both local government and community engagement. In a way this has to include improving security of tenure for rural people through decentralization with clear and implementable legislation, statutory recognition of customary laws and conventions governing land and natural resource tenure, and the engagement and buy-in of both state and local institutional actors. Bribery in resolving conflicts was repetitively mentioned during FGDs implying that land governance interventions including land rights awareness creation are critical. The question of bribery at a local level has been reported in other studies as well. Mwamfupe [14] for example reports corruptible leadership of the Local Government Authorities in Tanzania in the course of resolving farmer-pastoral conflict whereby upon accepting bribe from the pastoralists, village leaders allow large herds of cattle beyond the capacity of the village land thereby exacerbating conflict.

\subsection{Land Conflict Management Mechanisms Set in Place}

Table 9 presents ways used to resolve land conflicts in the landscapes. The results showed a variety of means used by the communities. Exactly $57.5 \%$ of the respondents reported the village land council. This is a small committee of the village council. Others reported arbitration between the parties, and ward tribunals. In cases, where some conflicts have not been successfully resolved by the councils and tribunals, other higher authorities such as the district land housing tribunals intervened.

Table 8. Awareness of land allocation and land use planning bylaws

\begin{tabular}{|c|c|c|c|c|c|}
\hline Response & $\begin{array}{c}\text { Sumbawanga-Mtowisa } \\
(\mathrm{n}=90)\end{array}$ & $\begin{array}{c}\text { Kasanga-Matai } \\
(n=59)\end{array}$ & $\begin{array}{l}\text { Mwese-Mwamankulu-Sitalike } \\
(\mathrm{n}=60)\end{array}$ & $\begin{array}{l}\text { Kate-Chala } \\
\quad(n=61)\end{array}$ & $\begin{array}{c}\text { Total } \\
(n=270)\end{array}$ \\
\hline Village land use by law & 21.5 & 12.2 & 19.6 & 18.1 & 71.5 \\
\hline Village natural resource by-law & 14.8 & 15.9 & 15.6 & 20.0 & 66.3 \\
\hline Village water resource by-law & 20.7 & 14.4 & 16.3 & 17.4 & 68.9 \\
\hline Rangeland management by-law & 1.1 & 0.0 & 0.4 & 0.0 & 1.5 \\
\hline Village fisheries by-law & 2.2 & 4.8 & 0.7 & 0.0 & 7.8 \\
\hline Forest protection by-law & 6.3 & 3.0 & 3.7 & 1.9 & 14.8 \\
\hline Not aware & 4.4 & 1.1 & 1.9 & 1.1 & 8.5 \\
\hline
\end{tabular}

Table 9. Methods to resolve land conflicts

\begin{tabular}{|c|c|c|c|c|c|}
\hline Ways to resolve land conflicts & $\begin{array}{c}\text { Sumbawanga-Mtowisa } \\
(\mathrm{n}=46)\end{array}$ & $\begin{array}{c}\text { Kasanga-Matai } \\
(n=41)\end{array}$ & $\begin{array}{c}\text { Mwese-Mwamankulu- } \\
\text { Sitalike }(n=18)\end{array}$ & $\begin{array}{c}\text { Kate-Chala } \\
(n=41)\end{array}$ & $\begin{array}{c}\text { Total } \\
(n=146)\end{array}$ \\
\hline $\begin{array}{l}\text { Agreements between the parties } \\
\text { involved in the conflicts }\end{array}$ & 2.7 & 2.7 & 2.1 & 4.1 & 11.6 \\
\hline Village land council & 15.8 & 18.5 & 6.2 & 17.1 & 57.5 \\
\hline Ward tribunal & 9.6 & 2.7 & 2.1 & 2.1 & 16.4 \\
\hline District land housing tribunal & 0.7 & 0.0 & 2.1 & 2.7 & 5.5 \\
\hline Elders/Religious leaders & 0.0 & 3.4 & 0.0 & 0.0 & 3.4 \\
\hline Not yet resolved & 2.1 & 0.0 & 0.0 & 2.1 & 4.1 \\
\hline It was resolved at the division level & 0.0 & 0.7 & 0.0 & 0.0 & 0.7 \\
\hline Police & 0.7 & 0.0 & 0.0 & 0.0 & 0.7 \\
\hline \multicolumn{5}{|l|}{ Total } & 100.0 \\
\hline
\end{tabular}


Despite the efforts of the village councils and ward tribunals to resolve land conflicts, the councils and tribunals are faced with the major challenge of incapacity that they are not capable of administering successful resolution of land conflicts. For example, it was reported, during FGDs, that one reason facing the village councils is that they are not complete judicial entities, and are, therefore, not likely to have an appreciable impact on the incidence of land litigation. Hence the role of local government intervention in resolving land conflicts is limited to arbitration level although they are mandated by law to resolve land conflicts. It is clear from these results that the capacity to resolve land conflicts especially among village councils is low and therefore requires intervention for improvement. The interventions needed include promotion of joint village land use agreement, in case two or more villages are involved in the conflict. In addition to formal institutional arrangements for land conflict management, there were informal institutional arrangements used to resolve land conflicts. For example, discussions during FGDs at Mtowisa ' $A$ ' revealed that:

We use the elders to settle land related conflicts. For example, just last year [2015] there was land conflict in one of the families in the village and the elders were asked to intervene and the conflict was successfully resolved (FGDs at Mtowisa 'A').

Therefore, the quotation from FGDs underscores the significance of supporting the informal institutions for capacity building and coordinated efforts with formal arrangements to successfully resolve land related conflicts.

\section{Conclusions and Policy Recommendations}

Based on the discussions of this paper, it is concluded that land governance in Tanzania is carried out through both statutory and customary arrangements. This is a 'legal dualism' system that had been in place since the colonial period and which shows challenges in its implementation through overlapping and duplication of activities. Within this framework, local governments have a role to play in the governance of land. While at a village level, village governments have a significant role to both allocate land and resolve land related conflicts. The local institutions remain at the cross-roads in terms of implementation. One problem being the legal capacities to resolve conflicts while the other being confusions arising from the interpretation of the so called customary land laws. Consequently, the capacity to reconcile between statutory and customary law emerges central to the major challenges already in place. In addition to this, women as subjects of both customary and statutory provisions face huddles in relation to land allocation, ownership and control. This is particularly true as customary procedures favour male subjects mainly because of the patriarchy system.

The paper recommends that more effort is needed to resolve land related conflicts by ensuring justice in land allocation, ownership, and control. To achieve this, efforts should include holistic community engagement in terms of mass education that focuses on both local government and the communities. Efforts should also include identifying a clear interface and providing correct interpretation of the relationship between customary and statutory procedures on land issues. This should further include more resources to the local councils to facilitate land administration including land survey and demarcation. Efforts should also be made to avoid uncoordinated interventions between formal and informal land arrangements to improve land management and combat land conflicts that deter communities' livelihoods.

\section{Acknowledgements}

The study did not benefit any external source of funding. However, authors acknowledge support, during data collection, from village governments and smallholder farmers.

\section{Competing Interests}

The authors have no competing interests.

\section{References}

[1] African Union Commission -AUC (2010), Land Policy in Africa: A Framework to Strengthen Land Rights, Enhance Productivity and Secure Livelihoods, AUC-ECA-AFDB Consortium, Addis Ababa.

[2] Benjaminsen, T.A., Maganga, F.P and Abdallah, J.M. (2009). The Kilosa killings: political ecology of a farmer-herder conflict in Tanzania. Development and Change 40 (3): 423-445.

[3] Coldham, S., (1995), Land Tenure Reform in Tanzania: Legal Problems and Perspectives. The Journal of Modern African Studies, Vol.33, No.2, pp. 227-242.

[4] Daley, E., Flower, C., Miggiano, L. and Pallas, S., (2013), Women's Land Rights and Gender Justice in Land Governance: Pillars in the Promotion and Protection of Women's Human Rights in Rural Areas, International Land Coalition Network, Rome.

[5] Fairley, E., (2012), Upholding Customary Land Rights through Formalization: Evidence from Tanzania's Program of Land Reform, paper prepared for Presentation at Annual World Bank Conference on Land and Poverty, April 23-26, 2012, World Bank, Washington DC.

[6] Fauz, T., (1996), The Dilema of the Customary Landholder, The Conflicts between Customary and Statutory Rights of Occupancy in Tanzania, in Robert Debusmann etal.(eds.), Land Law and Land Ownership in Africa Case Studies from Colonial and Contemporary Cameroun and Tanzania, Bayreuth, Germany, pp.81-112.

[7] Gastorn, K., (1995), Squatter's Rights and the Land Laws in Tanzania, Law and Politics in Africa, Asia and Latin America, Vol.43, No.3, pp. 349-365.

[8] HAKIARDHI (2009), The changing Terrain of Land Use Conflicts in Tanzania and the Future of a Small Producer, Land Rights Research and Resources Institute - HAKIARDHI, Dar es Salaam.

[9] Kabote, S.J., Nombo, C.I., Urassa, J.K., Mattee, A.Z., Mamiro, D.P and Masolwa, L.M (2016). Gender responsive adaptation to climate change in semi-arid environments of Tanzania is achievable. EPINAV policy brief No. 01/2016. Sokoine University of Agriculture, Morogoro.

[10] Kabote, S.J., Niboye, E.P and Ringo, J.J. (2014). International land deals and rural poverty reduction in Kisarawe District, Tanzania: in International Land Deals in Eastern and Southern Africa (edited by Paschal B. Mihyo). Organization for Social Science Research in Eastern and Southern Africa (OSSREA). Pp. 99-121. 
[11] Kelsey, J., Hughes, A.K and Knox, A., (2011), Placing Land Rights at the Heart of Development: Challenges of Local Land Governance in Mali, [Online] available at https://agriknowledge.org/downloads/rb68xb881 Viewed on 18 Feb. 17.

[12] Land and Natural Resource Tenure in Africa Program. (2010) Focus in Land in Africa Brief: Tanzania. Land and Natural Resource Tenure in Africa Program. 4pp.

[13] Larsson, P., Eidenstedt, L., Mutakyamilwa, F.K., and Herman, N., (2006), The Challenging Tanzanian Land Law Reform: A Study of the Implementation of the Village Land Act, Royal Institute of Technology, Stockholm

[14] Mwamfupe, D., (2015), 'Persistence of Farmer-Herder Conflict in Tanzania' in International Journal of Scientific and Research Publications, Vol. 5, No.2, pp.1-8.
[15] Olengurumwa, O.P.K. (2010). The 1990's Tanzania Land Laws Reforms and its Impact on the Pastoral Land Tenure. A paper to be presented during pastoral week at Arusha from 14th-16th February, 2010. 24pp.

[16] Shivji, I.G.1998. Not yet Democracy: Reforming Land Tenure in Tanzania. Dar es Salaam: Salaam IIED/ Hakiardhi

[17] The United Republic of Tanzania (URT) (1997), National Land Policy, $2^{\text {nd }}$ Edn., The Ministry of Lands and Human Settlements, Dar es Salaam.

[18] United Republic of Tanzania (URT) (2016). National Five Year Development Plan 2016/17 to 2020/21. Ministry of Finance and Planning. Dar es Salaam. 293pp.

[19] The United Republic of Tanzania (URT) (1999), Tanzania Land Act of 1999, Dar es Salaam.

[20] Wanitzek, U and Sippel, H. (1998), Land Rights in Conservation Areas in Tanzania, Geojournal Vol. 46 No.2, pp.113-128. 